\title{
Herpes Simplex Virus 6 Antibody Measurement
}

National Cancer Institute

\section{Source}

National Cancer Institute. Herpes Simplex Virus 6 Antibody Measurement. NCI

Thesaurus. Code C112292.

The determination of the amount of herpes simplex virus 6 antibody present in a sample. 